\title{
The Response of the Church of England to Economic and Demographic Change: the Diocese of Chester, 1818-1851 Brian Gobbett
}

ABSTRACT: The firse decades of the nineteen th century saw dramatic population growth and urbanization in England. Nowhere was this more so than in the diocese of Chester. In response to this changing demographic pattern, the Church of England made substantial administrative changes and was energetic in securing financial aid. Nevertheless, massive population growth, the traditional poverty and uneven revenue of Chester clergy, and an ineffective parochial system prevented the Church of England from adequately providing for the spiritual care of its parishioners.

Several national studies document the failure of the Church of England to respond successfully to the dramatic economic and demographic changes of nineteenth-century England.' A. D. Gilbert, one of the most perspicacious observers of the Victorian church, argues that by 1830 Anglicans were on the verge of becoming a minority religious body. ${ }^{2}$ There are, however, few examinations at the local or diocesan level which discuss the specific administrative difficulties facing the Church. ${ }^{3}$ More than any other diocese Chester, in the first half of the nineteenth century, illustrates these difficulties. It was to cities such as Liverpool and Manchester, firmly entrenched within the diocese of Chester, that individuals such as Benjamin Disraeli, Thomas Carlyle, and Charles Dickens went ro see both the problems and the potential that massive demographic growth had brought. Such cities were, as Asa Briggs notes, the shock cities of the age and a portent of what the future would hold. ${ }^{4}$ The Church of England likewise recognised the prevailing situation in Chester: each of the bishops appointed to the see between the First Building Commission of 1818 and the Census of 1851 proved to be remarkably energetic 
in seeking financial aid and in advocating administrative reform. Nevertheless, rapid demographic change, the traditional poverty and uneven revenue of the see, and the rigid parochial system hindered the energetic efforts of the bishops. By mid-century, despite a level of financial aid and administrative change that exceeded any other see, the Church of England's failure to put "bums in pews" was readily apparent.

The century prior to the Census of 1851 was marked by great change: dramatic population growth, a demographic shift towards urban areas, and a rapid growth in the productive capacity within some industries all combined to bring about a decisive transformation of English society. Although considered unreliable, the 1801 Census recorded the population of England and Wales at just below nine million. Five decades later, the 1851 Census reported a figure almost twice as great. 5 Perhaps as significant, as the masses migrated to cities and towns, the 1851 Census recorded that the majority now lived in urban areas. "It is evident," the Census commented, "... [that] the great cities will [be] ... the birthplace of a large part of the British race." Within the diocese of Chester, the counties of Cheshire and Lancashire experienced a doubling of their population during the first half of the nineteenth century, ${ }^{7}$ while Liverpool and Manchester increased more than four-fold. ${ }^{8}$

The effect of these dramatic changes upon the established Church was overwhelming. From its historical position of near monopoly, the Church of England had become, by the first quarter of the nineteenth century, merely one of the spiritual options in an increasingly pluralistic society. John Bird Sumner, Bishop of Chester between 1828 and 1848, who had earlier regarded England's population growth as a sign of divine favour, soon revised his view. Instead, as the meagre resources of the Church and ancient parochial system failed to provide for the needs of the populace, Sumner lamented that "the mass of the [adult] manufacturing population is... without religious instruction of any kind." 
Even before 1818 the diocese of Chester had a long tradition of poverty. In 1633 a commission held by order of the Archbishop of York concluded that "The ... [Chester] church was very indecent and unsemely [sic], the stalls thereof being parched and peeced [sic] and some broken, was much defiled with rushs and other filthiness." 10 An early nineteenth century observer concurred with this observation stating that "Chester ... is perhaps one of the least striking amongst those churches which contain episcopal thrones." 11 The great number of meagre livings which the diocese contained reflected this image of impoverishment. In 1818, fully 384 parishes in the see reported livings of under $£ 150$ per annum, the minimum level considered accepcable by the Church of England. ${ }^{12}$ Forty-seven parishes, moreover, were calculated at or below $£ 50^{13}$ with the parish church at Alvanley offering a return of only $£ 19$ for providing spiritual service to over 281 souls. $^{16}$ Despite a small increase in the number of parishes within Chester ${ }^{15}$ the Report of Ecclesiastic Revenues in 1835 noted that the number of livings under $£ 150$ had declined to 366 , and only nineteen provided less than $£ 50$. Alvanley, for its part, had increased its provision to $£ 47$ in providing care to its expanded population of $346 .^{16}$ However, alchough a trend towards more lucrative livings was established-particularly since the Report based its figures on a three-year average which included the recession of 1829-Chester still had an exceptional number of poor endowments. While Chester made up only 6 percent of the total benefices in 1835 , it accounted for nearly 13 percent of all livings under $£ 50$ and over 10 percent of all those reporting a means of under $£ 150.1^{17}$ This apparent poverty resulted in the Ecclesiastical Commissioners pursuing a policy of augmentation. In 1847 the Commission aided sixty-one Chester livings with grants of $£ 6,904$ in reaching the minimum standard of $£ 150$ per annum. ${ }^{18}$ Furthermore, the Commission funded an additional 287 parishes within the see with large populations and what were considered inadequate livings. ${ }^{19}$ In tocal, of the $£ 145,185$ expended in augmenting benefices throughout 
England and Wales during that year, Chester received $£ 41,854$, a sum that far outweighed most other dioceses. ${ }^{20}$

The revenues of the Bishop of Chester were similarly meagre. Prior to 1800 the Bishop could expect a net income of perhaps $£ 1,000$ per annum in return for administering one of the most expansive sees in England. ${ }^{21}$ The Second Ecclesiastic Commission of 1835 found that the Bishop's gross revenue had increased to $£ 3,261$ a year. ${ }^{22}$ By 1850 the Bishop's income over the previous seven years, which by now involved considerably reduced responsibilities following the formation of the sees of Ripon in 1836 and Manchester in 1847, was $£ 4,290$, though that figure was skewed upwards by the lucrative episcopal revenues of 1847 (see table 1). ${ }^{23}$ Nevertheless, Chester's revenues paled when compared to most other bishoprics. A correspondent of the Times calculated in 1832 that while Chester could claim an income of $£ 2,500$, the Bishop of Durham immediately to the north of Chester received $£ 18,000$, and that Bangor and St. Asaph's to the sourh totalled yearly revenues of $£ 5,000$ and $£ 6,000$ respectively. ${ }^{24}$ Moreover, the disparity in annual revenue, despite the desires of the EcclesiasticalCommission to promote greater equity amongst bishoprics, continued to increase. By 1850 Durham reported an episcopal income of $£ 38,000$, with Bangor and St. Asaph's taking in sums of $£ 6,355$ and $£ 6,163$ respectively. ${ }^{25}$ As in the case of individual benefices, the Ecclesiastical Commission followed a policy of augmentation in dealing with the relative poverty of the Bishop of Chester. In 1836 an Act of Parliament had set the average intended income of the bishopric at $£ 4,500 .{ }^{26} \mathrm{In}$ the fourteen years which followed this pronouncement, the Bishop of Chester was to reach this mark on only three occasions. ${ }^{27}$ Thus the Commission, buoyed by funds from episcopal and capitular estates, paid $£ 1,100$ to Chester in $1846^{28}$ and $£ 2,853, £ 2,626, £ 3,293$, and $£ 2,166$ in the four years following 1847.29 Despite presiding over one of the most populous and expansive sees, the Bishop of Chester's financial position remained firmly entrenched among the lower realms of episcopal revenue. 
Table 1: Gross Yearly Revenues of the Bishop of Chester

\begin{tabular}{ll} 
Year & Revenue (in pounds sterling) \\
1829 & 8,270 \\
1830 & 1,682 \\
1831 & 1,590 \\
1832 & 3,150 \\
1833 & 1,831 \\
1834 & 3,587 \\
1835 & 2,918 \\
1836 & 9,366 \\
1837 & 1,695 \\
1838 & 4,390 \\
1839 & 8,016 \\
1840 & 1,904 \\
1841 & 1,894 \\
1842 & 3,343 \\
1843 & 1,893 \\
1844 & 3,361 \\
1845 & 5,099 \\
1846 & 1,925 \\
1847 & 9,416 \\
1848 & 2,155 \\
1849 & 3,462 \\
1850 & 2,725 \\
\hline
\end{tabular}

Source: Parliamentary Papers, 1851, xlii. 69-71; 279-81; 393

The continued relative poverty of the diocese of Chester, as reflected in its preponderance of endowments under $£ 150$ and the meagre revenues of its Bishop, limited the effectiveness of the Church of England during a time of massive demographic change. Contemporary observers frequently noted that the primary consequences of the impoverished state of the established church were the plurality and non-residence of its clergy and the transitory nature of its bishops. In September 1832, several clergy and supporters of the Church met at George Inn, Newcastle-upon-Tyne for "the purpose of forming a society in the North of England 
for the protection of the Church Establishment," ${ }^{30}$ and strongly recommended that the plural holding of benefices by clergy be eliminated. Thomas Arnold, one of the more vigorous proponents of Church reform, echoed this sentiment when he declared in 1833 that the "evil of pluralities ... should be removed, because it is unseemly and discreditable." 31 Bishop Sumner, in his 1835 address to the clergy of Chester, exhorted ecclesiastic officials towards active participation in their parishes: "in one conclusion we must all agree," Sumner proclaimed, " ... that the leading object of our present anxiety must be the extension of the pastoral care, and the increase of spiritual provision." 32 Sumner himself maintained a policy of triennial visitation ${ }^{33}$ and proposed an organized system of district visitation to his clergy. ${ }^{34}$ Sumner was convinced that such action (in addition to other reforms) proved of great benefit to the Church. In examining the returns of ten parishes which had followed his recommendations he found that over a three-year period the average church attendance had increased by more than oneseventh. ${ }^{35}$ Clearly it remained dangerous to the well-being of the Church to limit, as Sumner described, the minister's "duty to the church walls." 36

The problems of clerical non-residence and pluralities were rooted in the inability of a single parish to provide an adequate living. While the Liverpool Mercury lauded the case of a certain young clergyman who, "for two sermons and a walk of forty miles each Sabbath ... received the paltry pittance of $£ 30, " 37$ less diligent clergy commonly augmented their income through plural residences. Bishop Blomfield, who presided over the see of Chester from 1824 to 1828 , served as a poor example in this regard since he held the rich living of St. Botolph's in commendan in addition to his bishopric. Moreover, the scarcity of adequate glebe houses reflected the poor state of episcopal finances in Chester: the 1835 Ecclesiastic Commission figures show that living arrangements were provided for only 38 percent of incumbents. ${ }^{38}$ While many no doubt lived in a nearby parish, other parishes contained no close residence. Thus, 
by necessity, these areas were served only on an infrequent basis.

The extremely large size of country parishes within Chester compounded the challenges of providing adequate spiritual care. The average Anglican parish size in the northwest counties comprised 11,860 acres, the largest average in the country. ${ }^{39}$ In contrast, Yorkshire parishes averaged just over 6,000 acres and counties in the east and southeast reported a more manageablesize of less than 2,500 acres. ${ }^{40}$ The size of Chester parishes revealed two hindrances: Chester clergy, particularly those with plural residences, could hardly be expected to minister effectively to the spiritual needs of parishioners no matter how great the incumbent's desires and energies. As well, large parish size effectively reduced church attendance. In 1852 a parliamentary inquiry into the need for church building indicated that a mile was considered the limit people could be expected to travel to worship, and that bad weather or poor roads could reduce this distance. ${ }^{41}$

In addition to the problems of plurality and nonresidence, the diocese of Chester experienced little continuity in its leadership. As a result of the poor financial rewards of the see, bishops tended to view Chester as a means to more lucrative appointments. Not only was revenue typically small, but it also tended to fluctuate widely. Such limitations did not act to encourage lifetime appointments: each bishop during the first half of the nineteenth century was ultimately translated to a more profitable venture. ${ }^{42}$ Given the administrative duties that accompanied this huge see it is not surprising that Bishop Blomfield declared that he left it without regret. ${ }^{43}$ Blomfield's sentiment was reflected in a local saying, "the Bishop of Chester never dies," 44 which alluded to the transitory nature of the bishopric.

The instability of his revenues further encumbered the Bishop of Chester's financial position. In 1829, the Bishop's revenues amounted to a surprising $£ 8,270$; 45 however, the next two years brought gross revenues of only $£ 1,682$ and $£ 1,590 .{ }^{46}$ This erratic pattern continued 
throughout the 1830s and 1840s: 1836 realized revenues of $£ 9,666$, while 1839 and 1847 brought $£ 8,016$ and $£ 9,416$ respectively. ${ }^{77}$ Conversely, revenues of under $£ 2,000$ were recorded in 1833,1837, 1841, 1843 and $1846 .{ }^{48}$ The erratic nature of revenues was due, in part, to the creation of new sees out of the ecclesiastical territory of Chester which severely limited the possible sources of income. In 1836, in response to the laborious nature of the see and recommendations of the Ecclesiastical Duties and Revenues Commission, the diocese of Ripon was created. The decrease in territory, in which the population dropped from almost two million to $1,200,000,{ }^{49}$ no doubt reduced ecclesiastic revenues. A comparison of the returns from 1836 - the year of the creation of the new see-to 1837 indicare a drop in revenue from $£ 9,366$ to $£ 1,695 . .^{50}$ Similarly, the archdeaconry of Manchester-which had been formed from the deaconries of Blackburn, Manchester, Leyland, and Warrington in 1843-was translated into a new diocese in 1847. Accordingly, revenues of the Bishop of Chester dropped from $£ 9,416$ in 1847 to $£ 2,155$ in the following year."

A second factor influencing the erratic nature of the Bishop's income was the fluctuating income garnered from fines on renewals of leases. The system of fines on renewals operated on, as the Episcopal Revenues Commissioners noted, the tenure of church property by lease, "either for three lives, renewable at the dropping of any one life; for 21 years, renewable at the expiration of every seven; for 30 years, renewable every 10; or for 40 years, renewable every 14." 52 A fine, the principle source of emolument (rather than the annual rent), was levied at each period of renewal. Such a system, vircually unbreakable by the time the of Ecclesiastical Commissioners, ${ }^{33}$ created uncertainty for borh the tenant and the lessor. Lessees were often unwilling to sink large amounts of capital into these lands and expressed fear over future rents and about the security of their tenure. ${ }^{54}$ For the Church several significant problems arose. First, as the 1837-9 Committee on Church Leases showed, church 
lands were not being improved in as fruitful a manner as freehold lands. 55 Thus, the commissioners of the 1850 report on Episcopal Revenues lamented the low recurns on church lands and declared that "there is little doubt that, under a different plan of management, the estates might be made to produce a much larger income for the Church." 56 Second, and of particular significance in explaining the erratic nature of Chester's episcopal revenues, huge windfalls might be expected during years of renewal, while in other years little income would be realized. Of the rich return of $£ 8,270$ in $1829, £ 6,535$ was derived from renewal fines: ${ }^{57}$ conversely, the paucity of renewal fines in 1830 and 1831 accounced for the low episcopal revenues in those years. $^{58}$ Thus the system of church leases disadvantaged the Church at Chester in two ways. Whatever holdings the financially strapped see maintained were not utilized in their most productive fashion. In addition, the erratic nature of letting leases often handicapped the Church during a period of great challenge. The uncertain nature of Chester revenues was further threatened in that most of its leases were let in lives. ${ }^{59}$ As a result renewal fines proved to be even more unpredictable than those dioceses which had a greater dependence upon leases for years.

A final aspect of the church lease system that contributed to a pattern of uneven revenue was its dependency upon the local economy. In times of plenty, the ready resources of the tenant led him to seek a renewal prior to the expiration of the lease. In 1836, for example, a year of favourable economic growth, ${ }^{60}$ there were renewal fines of $£ 7,850$ within the see. ${ }^{61}$ In contrast, during times of economic uncertainty, such as the recession of 1837 or the more serious downturn of 1841-42, renewals of leases with years (or lives) still remaining tended to be less frequent. In both 1837 and 1840, the Bishop received no revenue from renewal of leases and 1841 produced fines amounting to only $£ 1,769$, a meagre figure when compared to the substantial amounts received in 1836 and $1839 .{ }^{62}$ 
The Church actively pursued church extension as a solution to the demographic exigencies it faced. In 1818 the Church of England was in severe difficulties in attempting to accommodate parishioners within Chester. Stockport had a population of 33,973 , but provided seating for only 2,500 individuals. Similarly Liverpool and Manchester, the two largest centres within the diocese, had populations of 94,376 and 79,459 , but searing for only 21,000 and 10,950 , respectively.$^{63}$ Even though smaller centres fared better than large urban areas, towns such as Balderston, with a population of 2,000 and seating for only 450 or Ringley with 3,000 souls but accommodation for only 350 , fell considerably short of the standard expected by many churchmen of the day. ${ }^{64}$ Although similar concerns were felt across England, only London, with accommodation for just 11 percent of its population, approached the magnitude of the difficulties felt in Chester. ${ }^{65}$ Such shortages clearly were seen as dangerous to sociery. Viscount Sidmouth, in the House of Lords, spoke of "the great and increasing evil which arose from want of a sufficient number of Places of Worship of the established church." ${ }^{66}$ Sidmouth, in pursuing such an argument concurred with Joseph Addison, who, a century earlier had written:

the country-people would soon degenerate into a kind of savages and Barbarians, were there not such frequent Returns of a stated time, in which the whole Village meet together with their best faces, and in their Cleanliest Habits, to converse with one another upon indifferent Subjects, hear their Duties explained to them, and join together in Adoration of the Supreme Being. ${ }^{67}$

Prior to 1817 the Church had been limited in its ability to secure funding: briefs, church rates and voluntary subscriptions had been the primary sources of funds available for church extension. ${ }^{68}$ None of these sources, however, was adequate to provide for the growing needs of the Church. The ancient system of briefs, a letrer patent issued by the 
sovereign which licensed a collection for specified objects, was in little use and abolished in 1828. ${ }^{69}$ Church rates, which had originated in the common-law practice of having each parish keep its church in repair, ${ }^{70}$ increasingly came under attack in a society marked by spiritual plurality. Dissenters had been expected to contribute to the Established Church as well as, presumably, participate in the financial obligations of their own faith. Thus they were expected to pay twice, with one contribution going to a source with which they had fundamental differences. Chester, which had strong elements of dissent in Stockport and Macclesfield ${ }^{71}$ and a significant Roman Catholic population, particularly at Liverpool, ${ }^{72}$ often resisted or ignored the pressure to contribute to Church rates. As a result, these groups played little part in church extension.

The formation of the Church Building Commission in 1818, which built upon the foundations of a national society advocating church accommodation, led to Parliament's first massive venture into the material provision of the established Church. Significantly, among the thirtyfour members on the initial Commission was George Henry Law, the Bishop of Chester until his translation to Bath and Wells in 1824. The Commission's first effort, preceded by the Chancellor of the Exchequer's opening speech proclaiming the shortage of church accommodation, ${ }^{73}$ was the Church Building Act of 1818 which set aside one million pounds in Exchequer Bills for providing "a proper accommodation for the largest number of persons at the least expense."74

The expenditures during the first six years of the Commission reveal the sense of urgency which members of the Church in Chester no doubt felt. Of the $£ 1,068,000$ spent, over $£ 214,000$ was assigned to the construction of twenty churches in Cheshire and Lancashire. ${ }^{75}$ In comparison, the diocese of London received a total of just over $£ 159,000$ and other areas were dealt with less generously. ${ }^{76}$ The 1824 Parliamentary Grant, which distributed a half-million pounds over the next three decades, 
was equally beneficial to Chester; just over $£ 100,000$ for aid in the building of eighty-four churches was allotted to the see. ${ }^{77}$

Several factors account for the disproportionate size of Parliamentary grants to Chester. Most obviously, the spiritual needs of a growing population called for a response from the Church establishment. Cheshire's population had grown from under 200,000 in 1801 to well over 400,000 by 1851. More dramatically, Lancashire's population had exploded from under 700,000 to over two million. ${ }^{78}$ London, of course, exhibited a similar growth and had brought a like response from the Church Building Commission. ${ }^{79}$ Yet demographic demands did not account fully for the Commission's allotment. The coterminous county and archdeaconry of Durham more than doubled during the first half of the nineteenth century, achieving one of the fastest rates of growth in the country. ${ }^{80}$ Despite having a population nearly equal to that of Cheshire, Durham received Parliamentary grants of only $£ 6,120$ during the initial phase, and $£ 4,731$ in the subsequent allotment. ${ }^{81}$ Significantly, the Bishop of Durham was not included in the original Church Building Commission while George Law was. ${ }^{82}$ Moreover, each of the three Chester Bishops who served on the Commission-George Law, Charles Blomfield and James Bird Sumner-proved to be vigorous advocates of church extension. Law showed his eagerness when in 1820 he wrote to Lord Liverpool that "as the building of the new churches at Manchester and its neighbourhood proceeded slowly, I thought it advisable to expedite the business [of church design], by looking after it on the spot." ${ }^{13}$ In addition, since the Commission responded to outside proposals, as well as the desires of its own members, Law quickly urged a protege of his own, Thomas Rickman, to prepare plans for Chester "in order that no time might be lost." ${ }^{84}$ Charles Blomfield, who had prepared himself to be a bishop since he was a young man, later showed his vigour by establishing himself as a key member of the Ecclesiastical Commission: "til Blomfield comes," the Archbishop of 
York was heard to proclaim, "we all sit and mend our pens, and talk abour the weather. ${ }^{\text {"8s }}$ Sumner, who served as bishop for two decades, exhibited similar zeal. In 1843 Robert Peel acknowledged the efforts and influence of Sumner:

it would not be just, were I not to express, in strong terms, my admiration of the conduct of the Bishop of Chester, who had effected so much improvement in that diocese which has the good fortune to be under his charge, and to witness his example.... In the diocese of Chester, in the year 1841, the sum of $£ 53,000$ was applied to the building of Churches. ${ }^{86}$

Parliamentary grants were not the only, and indeed not even the primary, source of funding church extension. The philosophy of the Commissioners of the Second Parliamentary grant dictated that local contributions would be necessary for successful application. While the initial Parliamentary grant covered the whole cost of the twenty churches built (save for $£ 224$ ) ${ }^{87}$ the second disbursement provided for just 46 percent of the total cost. ${ }^{88}$ Increasingly, Whig opposition and the voices of dissent argued against the government-sponsored building project. As a result, the grants were of smaller amounts, more frugal church designs were chosen, and local subscriptions more heavily relied upon.

The pursuit of local subscriptions produced uneven results. The diocesan Church Building Society was established in Chester in 1835 and over the next decade it solicited contributions of only $£ 8,250$ for church building in urban areas. ${ }^{89}$ Its sister organization, the National Church Building Society, proved to be slightly more lucrative; by 1851 it had aided fifty-six churches within Chester with an expenditure of $£ 10,090 .{ }^{90}$ In Liverpool the Incorporated Church Building Society was established in 1828 and contributed 132 grants worth over $£ 27,000$ for church extension over the next nine years. Of greater importance than the various societies that existed, however, were innumerable contributions by private 
citizens. Peel, in expressing adulation for Sumner, had noted that although " $£ 18,350$ [was] derived from public sources ... let it be said, that $£ 46,500$ were provided by individual subscriptions." Such an example showed, Peel continued, that "the tendency of advancing small sums is to produce a supply from individual exertion far exceeding them." 11 Likewise, Bishop Sumner estimated that in 1839 over 60 percent of church building monies came from local contributions, 11 percent from the Commissioners and church building societies, and a further 28 percent from other trusts and public organizations. ${ }^{22}$

The bulk of local contributions-at least in the countryside-were inspired by the Church Building Act of 1831. The Chester gentry responded favourably to this act which granted parronage to individuals who built a church and provided an endowment of at least $£ 1,000 .{ }^{93}$ Between October 1832, when the first church was endowed in Salford, until 1851 , seventy-four churches were built within the see as a direct result of the Church Building Act. ${ }^{94}$ Such efforts illustrate, as in the Parliamentary grants of 1818 and 1824, the energetic efforts of the established Church in Chester. In comparison the 1831 Act produced only five churches in Durham, a similar number inCarlisle, and one each in Bangor and St. Asaph. ${ }^{95}$

Liverpool, along with Manchester and other smaller urban centres, bore the brunt of population growth and demographic change. Its response relied heavily upon the funding and patronage of the Mayor and Common Council.\% As early as 1828 Blackwood's reported that the "Corporation of Liverpool [is] said to have solicited the erection of a Bishopric, for which they are in return to show their zeal by the erection of a cathedral." 97 Though Liverpool failed to acquire its own diocese until 1880 - by which time the Council had long ceased to act as a patron-it vigorously advocated church growth within its boundaries: St. Luke's, for example, "was built entirely by the corporation ... at a cost of $£ 53,418$ [which was] incurred from 1823 to 1832 ." Similarly, over $£ 45,000$ was invested in St. George's and 
$£ 16,000$ in St. Michael's.9 Indeed the sums of money invested by the Corporation were considered so exorbitant by some that they were a "special ground of complaint."100 In addition, the 1835 Ecclesiastical Commission showed that of Liverpool's twenty-seven Anglican churches, the Council endowed fifteen with livings. ${ }^{101}$ To ensure spiritual service to the parishioners of St. Luke's, for example,the Commissioners on Municipal Corporations noced that two clergymen were provided to serve the church and that neither has "any other preferment, and both reside and perform [their] duries." 102 This patronage, of course, ended with the Municipal Corporations Act in 1835 and the outgoing Tory Council, in an effort to protect church revenues to some extent, set up an endowment fund of $£ 105,000 .^{103}$ Although the Corporation was forced to sell its patronage, an agreement reached with the reformed Council allowed it to continue to pay for stipends and church maintenance for most of the nineteenth century. ${ }^{104}$

The realities of demographic shift also predicated administrative changes within the long established parochial system. Since the revenues of dioceses and parishes were considered the private property of Church officials, any altering of ecclesiastical boundaries was met with hostility. Blackwood's opposed the establishment of a Liverpool bishopric in 1828 because "Bishop Blomfield deserves the richest see of them all; and even if he should be translated, his successor will have to stomach the mortification." ${ }^{105}$ But the size of the Chester diocese, its massive population increases, and the relative poverty of the see, combined to act as a catalyst to structural change. In 1836 the new see of Ripon was formed out of the northern deaneries of Richmond, Catterick, Boroughbridge, and western Lonsdale. Similarly, the creation of the see of Manchester in 1847 absorbed much of the central regions of the diocese, while the peculiar of Hawarden was transferred to St. Asaph in 1849. Since the creation of Manchester effectively separated the southern part of the diocese of Chester from its northern half, litcle administrative benefit inicially occurred. The 
administrative unity of Chester was restored in 1856 with the transfer of the deaneries of Copeland, Furness, Cartmel, and parts of Kendal and Kirby Lonsdale to Carlisle.

In addition to a structural redefinition of Chester's diocesan boundaries, the Church made important changes in the administration within individual parishes. In a speech before the 1843 Parliament, Robert Peel lamented that in "the diocese of Chester, there are thirty-eight parishes or districts in Lancashire, each with a population exceeding 10,000 ." 100 Such masses of humanity, of course, overwhelmed the resources of the parish. As a result, Peel introduced a bill which established ecclesiastical districts-staffed by curateswithin populous parishes. This bill did not seek to increase church accommodation; rather it provided $£ 30,000$ per annum for the endowment of clergy within these districts, even if it was necessary to hire a building in order to conduct services. ${ }^{107}$ Chester responded quickly to the creation of Peel districts. By 1845 twenty-two new districts had been established within che see; Ripon, by contrast, had established eight and Durham only two. ${ }^{108}$ Significantly, the right of advowson, and the obligation of providing livings, fell to the Crown and the bishops. Thus, since patronage was provided from outside the parish, little infringement occurred upon the revenues of the incumbent. Still, the curates of the new districts rarely received the maximum endowment of $£ 150$ recommended by the Commissioners and tended to preside over unappealing districts. ${ }^{109}$ One incumbent, William Rogers of Charterhouse, reflected on the impoverished state of the districts stating that "the mother parish ate the oysters; the districts divided the shells." 110 While these measures no doubc broke populous parishes into more manageable units, they did not result in intimate spiritual care. By the mid1840s the districts established in Manchester still averaged more than 4,000 souls, while those in Stockport contained over 5,000."'I Although Peel's objections to parishes of over 10,000 individuals had been addressed somewhat, it is unlikely that pastoral care improved significantly simply by creating districts which encompassed half that number. 
The Church of England within the diocese of Chester was poorly equipped to react effectively to the demographic changes which embraced England during the first half of the nineteenth century. Though a small minority of clergy retained wealchy livings, ${ }^{112}$ most (including the bishop) had small or erratic incomes. Moreover, the large parish size and rigid parochial system were more suitable to an earlier century rather than one marked by massive demographic changes. Despite large amounts of money and significant administrative changes, the weakness of the Church within Chester was clearly apparent by mid-century. In 1851 the census reporred that Manchester could provide for only 12 percent of its population and Liverpool for just 16 percent. Similarly, the counties of Cheshire and Lancashire could provide seating for less than 20 percent of their population. ${ }^{113}$ Despite the efforts of some of England's most energetic bishops, the Church's efforts to provide pews and intimate spiritual care to the parishoners of Chester had met with little success. 


\section{NOTES}

' For example, sec R.A. Soloway, Prelates and People, (London, 1969); W.R. Ward, Religion and Society in England. (London, 1972); and A.D. Gilberr, Religion and Society in Industrial England, (London, 1976).

${ }^{2}$ Gilhert, Religion and Society in Industrial England, 27

"A notable exception is W.B. Maynard, "The Response of the Church of England to Economic and Demographic Change: the Archdeaconry of Durham, 1800-1851," Journal of Ecclesinstic History 42 (July, 1991).437-462.

4 Asa Briggs, Victorian Cities (Harmondsworth, 1968), 96

'Census, 1851. P'opulation. ccviii

'Cited in P. Mathias, The First Industrial Nation, 2nd edition (London. 1983), 226

- Census. 1851. Population. ceviii

${ }^{8}$ Mathias places the population of Liverpool and Manchester in 1801 at 82,000 and 75,000 , respectively; the 1851 Census records the population of these cities as 375.955 (a growth of 458 percent) and 303,382 (404 percent); Mathias, 417; Census, 1851. Population. ccviii. "J.B. Sumner, A Charge Delivered to the Clengy of the Diocese of Chester. (1832), 12; cited in Soloway, Prelates and People, 309.

${ }^{10} \mathrm{~B}$. Windle, Chester, (London, 1903; report, East Ardsley, 1970), 159 "Ibid., 153

12 Parliamentary Papers (hercinafter PP), 1818, xviii. 183-191

13 Ibid

14 Jbid.. 190

15 The Parliamentary report on the number of parishes requiring augmentation in 1818 shows Chester having 586 parishes; the 1835 Report on Ecclesiastic Revenues puts that figure at 630 . Of course some allowance, particularly in the 1818 figures, must be made for parishes not making returns or for erroneous recording.

16 PP. 1835, xxii. 5

1- Jbid.. 231-234

is PP. 1847, xxxiii. 22

19 lhid., 23

${ }^{20}$ Durham and Carlisle, for example, received augmentation amounting to $£ 8,506$ and $£ 6,280$ respectively. Only the diocese of York surpassed Chester, receiving a grant of $£ 43.356$. PP, 1847, xxxiii. 23

21 R.B. Walker, "Religious Changes in Cheshire, 1750-1830," Journal of Ecclesinstical History. 27 (1966), 77

${ }^{22}$ PP. 1835, xxii. 30-1

${ }^{23}$ PP. 1851, xlii. 279-81; 393

${ }^{24}$ Liverpool Mercury, 13 April 1832, 115

"PP, 1851, xlii. 93

${ }^{26} 6$ \& 7 William IV. c. 77 
27 See Table 1: Gross Yearly Revenues of the Bishop of Chester.

${ }^{28}$ PP. 1847, xxxiii. 247

${ }^{29} P P, 1852-3$, lxxviii. 234

${ }^{30}$ London Times, 8 November 1832

"T. Arnold, Principles of Church Reform, (1833; report, London, 1962), 139

${ }^{32}$ J.B. Surnner, $A$ Charge Delivered to the Clengy of the Diocese of Chester. at the Triennial Visitation in 1835. (London, 1836), 19

${ }^{3}$ A.T. Thacker, "The Diocese of Chester," in A History of the County of Chester, ed. B.E. Harris, (Oxford, 1980). 1II,54

${ }^{3}$ Sumner, Triennial Visitation, 25

"Ibid., 27

${ }^{36}$ Ibid. The popular press also perceived non-residency as a problem within the Church. The Liverpool Mercury lamented "that out of 10,500 parishes, there were scarcely so many as 6,000 sesident." 11 February 1831, 42.

37 Liverpool Mercury, 22 June 1832, 198

${ }^{38}$ PP, 1835, xxii. 1.229

${ }^{39}$ Cilbert, Religion and Sociery in Industrial England, 100-101. The northwest counties include Cheshire and Lancashire. The average size of the northern counties-Cumberland, Durham. Northumberland and Westmorland-was 11,790 acres in 1811. Of course, two of these counties-Cumberland and Westmorland-were, in part, included within the diocese of Chester.

40 Ibid

"Gilbert, Religion and Society in Industrial England, 101

${ }^{42}$ Henry William Majedie (1800-09) was translated to Bangor; Bowyer Sparke (1809-12) to Ely; George Henry Law (1812-24) to Bath and Wells; Charles Blomfield (1824-28) to London; and even John Bird Sumner (1828-48) to the archbishopric of Canterbury. Sumner was succeeded by John Graham (1848-65). Walker, "Cheshire," 77-8. John Bird Sumner's lengthy appointment is explained by an increased tendency by the Crown to frown upon translations. Desmond Bowen, The Idea of the Victorian Church. (Montreal, 1968), 26.

13 Harris, ed., A History of the County of Chester. III.62

* Alfred Blomfield. Memoir of Charles James Blomfield (1864), 79; cited in Bowen. 17.

15 PP, 1851, xxii, 69

4 Ibid., 69-71

47 Ibid., 69-71; 279-81; 393

48 Ibid

49 Thacker, "The Diocese of Chester," 1II,63

so See Table 1: Gross Yearly Revenues of the Bishop of Chester.

"Ibid 
$52 P P, 1850, x x .35$. Depending upon the area and length of lease, the renewable fine usually was between one and a half to two years the annual value of the land. lbid., 36.

G.F.A. Best, Temporal Pillars, (Cambridge, 1964), 370

s4 Ibid., 371-2

" lbid., 372

${ }^{56}$ PP. 1850, xx. 36

57 Ibid. 69. Other years of lucrative bishopric returns can be traced to renewal fines: in 1836 renewal fines amounted to 17,800 ; in 1839 $£ 6,413$; in $1845 £ 3,110$; and in $1847 £ 7.516$. PP, 1851, xlii. 69-71; 279-81; 393 .

58 lbid

"97 The average for all English bishops was to let twice as many leases for lives as leases for years. PP, 1839, viii. 245; Best, Temporal Pillars, 371. Chester's dependence on leases for lives was considerably greater: of the $£ 44,574$ collected in renewal fines between $1829-1851$, only $£ 3,683$ was due to leases for years. PP. 1851, xlii. 69-71; 279-81; 393.

60 R.C.O. Matthews, A Study in Trade-Cycle History, (Cambridgc, 1954), 206-9

61 PP. 1851, xlii. 69-71; 279-81; 393

${ }_{62}$ Ibid. The lack of data in, for example, 1837 and 1840 is interpreted as evidence that there were no renewals in that particular year. Clearly the Ecclesiastical Commissioners interpreted the data in such a fashion: the figures given in the Commissioner's report were used in calculating the level of augmentation the Bishop of Chester would receive.

${ }^{63}$ PP. 1818, viii. 102-103

${ }^{64}$ Ibid. Horace Mann thought that every portion of the country should have accommodation for 58 percent of its inhabitants. Census. 1851. Religious Worship. exxiii.

6s PP. 1818,xviii. 102-103. London had a population of 771,810 and accommodation for 87,336 .

"Hansard, 1810, xvii. 770.

67. Joseph Addison, Spectator, 9 July 1711 ; cited in Gilbert, Religion and Society in Industrial England. 75.

"s Maynard, "The Response of the Church of England," 449

${ }^{69}$ M.H. Port. Six Hundred New Churches (London, 1961), 108; Maynard, "The Response of the Church of England," 449. The Oxford English Dictionary traces the system of bricfs to 1588 on the occasion of spending "thirteene [sid score pounds in distributing briefs for a gathering towards the erecting of a Colledge |sid." In 1661 Samuel Pepys mentioned in his Diary. "To Church, where we observe the trade of briefs is now come up to so constant a course every Sunday, that we resolve to give no more to them."

${ }^{70}$ Dr. Dealtry. Chancellor of Winchester, argued that "the imposition of rates for the reparation of churches has heen sanctioned by the 
immemorial usages of ages." British Critic 40(1832),325; cited in Port, Six Hundred New Churches, 103.

${ }^{71}$ Walker. "Cheshise," 81. As well, Sandbach, Knutsford. Wilmslow and Congleton contained strong elements of dissent within the county of Cheshire.

72 R.B. Walker, "Religious Changes in Liverpool in the Nineteenth Century," Journal of Ecclesiastical History 19(1968),198. Walker states that 25 percent of the population was Roman Catholic by 1831 . "Hansard, 1818, xxxvii. 1116-1131

74 Port. Six Hundred New Churches, 24

${ }^{75}$ Port, Six Hundred New Churches, 132-139. Compiled from Appendix One: Churches Built with the Aid of the First Parliamentary Grant. ${ }^{76} \mathrm{Ibid}$

"Port, Six Hundred New Churches, 140-173. Compiled from Appendix One: Churches Built with the Aid of the Second Parliamentary Grant. The actual amount was $£ 100,688$. The diocese of London outstripped Chester by receiving grants totalling $£ 173,589$.

${ }^{78}$ Census. 1851. Population. ccviii

79 The population of London increased from 958,863 in 1801 to 2,362,236 in 1851. Census. 1851. Population. ccviii.

${ }^{80} \mathrm{Ibid}$. The rate of growth was 162 percent. Maynard, "The Response of the Church of England," 442.

it Port, Six Hundred New Churches, 132-173

82 Ibid., 174-175

${ }^{83}$ Ibid., 17

It Ibid., 30

"s Owen Chadwick. The Victorian Church. (London, 1966), 1,133

${ }^{86}$ Hansard, 1843, lxviii. 1287

87 Port, Six Hundred New Churches, 132-139. The cost of churches built amounted to $£ 214,298$; the grant was for $£ 214,074$.

* Ibid., 140-173. The Second Parliamentary Grant amounted to £100,688; the churches built under this Commission cost $£ 220,360$.

99 Thacker, "The Diocese of Chester," III,65.

${ }^{90}$ Walker, "Cheshire," 87

"Hansard, 1843. Lxviii. 1287

${ }^{22}$ Thacker, "The Diocese of Chester," III,65

"Significantly, only two churches were built in Liverpool and only one in Manchester as a direct result of the 1831 Act. PP, 1852-3. Ixxviii. 18-19.

* PP, 1852-3, lxxviii. 18-19

99 Ibid.

"Chester, Congleton, Macclesfield and Richmond-according to the 1835 Report-contained the only other councils which acted as patrons. Their involvement, however, was minimal: Chester provided one living of 1164; Congleton, a single benefice (in a parish of almost 
$10,000)$ of $E 143$; Macclesfield. one living of $£ 214$; and Richmond a benefice of undetermined value. $P P, 1835$, xii. 1-229.

97 Blackwood's, 23(January 1828),90

is PP. 1835. iv. 2730

9) Ihid

${ }^{100}$ Ibid., 2729

${ }^{101}$ PP, 1835, xxii. 114

${ }^{102} P P_{1}, 1835$, iv. 2730

10: Walker, "Liverpool," 197

${ }^{104}$ [bid

${ }^{105}$ Blackood's, 23(January, 1828),90

10. Hansard, 1843, Ixviii. 1290

$100^{\circ}$ lbid., 1289-90

${ }^{108} P P 1846$, xxiv. 239-241

10r) Best, Temporal Pillars, 408-409

11' William Rogers, Reminiscences, compiled by R.H. Hadden, 1888 , 55; cited in Best. Temparal Pillars, 408.

"1 PP, 1846, xxiv. 239

112 In contrast to its obvious poverty, the diocese of Chester also contained four of the twenty-two benefices (or 22.2 percent) in England and $W$ ales valued at over $E 2,000$. PP, 1835, xii. 231-234

11". Census, 1851. Religious Worship. cclxi-cclxiii; cxci 